\title{
DEVELOPMENT OF FIRE RESISTIVE SEPARATING CONSTRUCTION CONSISTING OF STEEL BEAM AND FIREPROOF PARTITION WALL
}

\author{
森田 武 — $* 1$ 近藤史朗 — $* 2$ \\ キーワード : \\ 区画部材，鉄骨梁，耐火間仕切壁，巻付け耐火被覆， \\ 耐熱ロックウール
}

Keywords:

Fire resistive separating construction, Steel beam, Fireproof partition wall, Wrap-type fireproof covering, Heat resistant rock wool

\begin{abstract}
Takeshi MORITA
Shiro KONDO $* 2$

A separating construction consisting of steel beam and fireproof partition wall is developed. In the development of the construction, a full scale fire test and small scale fire tests are carried out in order to verify two performances. One performance is the interaction between beam and partition wall, and the other is thermal insulation capacity. As the result of tests, it is confirmed that the beam-wall interaction is not a problem, and that thermal insulation capacity depends on the temperature of beam. According to these results, a simplified calculation method of temperature on non-heated side of steel beam is proposed.
\end{abstract}

\section{1. はじめに}

本開発では, 鉄骨梁と非耐力耐火間仕切壁 (以下, 間仕切壁と略す) で構成される区画部材を対象とし，一方の側は盛期火災を受け，他 方の側は火災による熱影響を受けない場合を想定した。この想定条 件の例として，エレベーターシャフト等の可燃物量が極めて少ない 竪穴空間まわりの区画が挙げられる。設計上，居室側は盛期火災に なったとしても，竪穴空間は局所火災になることが多く，熱影響は 局所火源に近い範囲に限られる。そのため，火災による熱影響を受 けない側の梁の耐火被覆を省略できる可能性がある。

梁の片側の耐火被覆を省略できると, 耐火被覆材の使用量を半減 できるだけでなく，片側施工が可能な間仕切壁との組合せにより， 耐火被覆と間仕切壁の両方を片側から施工できるため, 例えば堅穴 空間内に足場を組む必要がなくなるなど，施工の省力化が図れる。

一方，現行の耐火認定制度では，部材ごとの性能評価・認定が行 われており，梁と間仕切壁を一体化した区画部材に関する性能評価 法が定められてない。しかし，梁と間仕切壁が一体となった区画部 材を開発するためには, 高温時における梁と間仕切壁の構造挙動や 温度性状等の相互作用を把握・評価する必要があると言える ${ }^{1)}$ 。

本開発では，片側のみを耐火被覆した梁と間仕切壁を一体化した 区画部材 (以下，合成区画と称す)を実現することを目的として，実 大試験体の載荷加熱実験によって梁と間仕切壁の相互作用を把握す るとともに, 部分模型試験体の加熱実験によって合成区画の仕様を 検討した。また，耐火時間・梁断面寸法・被覆厚等の種々の組合せ 条件に対応寸るため, 耐火性能検証法 ${ }^{2)}$ の考え方に準じて合成区画 の梁の鋼材温度算定式を導出し，裏面温度の予測方法を提案した。

\section{2. 実大試験体の載荷加熱実験}

\section{1 試験体}

試験体は 2 時間耐火を目標としたもの 1 体とした。試験体を図 1
に示す。梁は小梁を想定して H-250×125×6×9(SS400) とした。梁 長は $5,800 \mathrm{~mm}$ ，支点間距離は $5,400 \mathrm{~mm}$ である。耐火被覆材には巻付 けタイプの耐熱ロックウール(厚さ $65 \mathrm{~mm}$ )を用いた。間仕切壁は, 軽 鉄下地の片側に強化せっこうボード(厚さ $21 \mathrm{~mm})$ を 3 層張り付けた， 2 時間の耐火性能を有する市販品を用いた。耐火被覆は, 梁長さ方 向に約 $300 \mathrm{~mm}$ 間隔で梁の上下フランジに溶接ピンで固定するととも に間仕切壁にもビスで固定した。

試験体は, 梁を実験装置の支持架台 (単純支持) に設置し, 後述の 固定荷重作用下において, 梁中央部のランナー下面とスタッド上端 の隙間および下フランジ下面とせっこうボード上端の隙間が $20 \mathrm{~mm}$

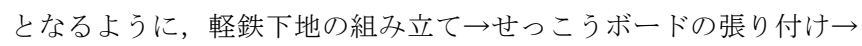
耐火被覆の施工の順で製作した。なお，間仕切壁の施工後，積載荷 重を作用させた時点のこれらの隙間は約 $15 \mathrm{~mm}$ であった。

\section{2 実験方法}

（1）荷重

実際の建築物における長期設計荷重の調査結果 ${ }^{3)}$ によると，鉄骨 梁の長期設計荷重時の曲げモーメントを長期許容曲げモーメントで 除した值 (M 比) は, 概ね $0.1 \sim 0.8$ の範囲にあることが報告されてい る。また，一般的な事務所建築物の設計例における小梁に作用寸る 固定荷重と積載荷重の割合を調べたところ, 固定荷重が $52 \%$, 積載 荷重が $48 \%$ あった。本実験では, 梁と ALC 板の自重を考慮して, M 比が 0.8 になるように, 梁支点間の 3 等分点となる 2 点に各々 $20.8 \mathrm{kN}$, 合計 $41.6 \mathrm{kN}$ の錘(鋼材)を載せて鉛直荷重を作用させることとした。 実験手順としては，施工の実情を考慮して，まず固定荷重相当の錘 $(21.6 \mathrm{kN})$ を梁上の 2 点の載荷位置に荷重が均等に作用するように載 せて間仕切壁を施工し, その後, 積載荷重相当の錘 (20.0kN) を追加 して梁上に載せて，一定荷重下で載荷加熱を行った。

（2）加熱

耐火被覆の施工面を加熱側とした。梁の有効加熱長さは $4,000 \mathrm{~mm}$,

\footnotetext{
清水建設侏技術研究所 主任研究員 - 博士 (工学)

( ₹ 135-8530 東京都江東区越中島 3-4-17)

清水建設(料環境・技術ソリューション本部 主査・博士（工学）
}

Senior Research Engineer, Institute of Technology, Shimizu Corporation, Dr. Eng.

2 Manager, Environment \& Technical Solution Division, Shimizu Corporation, Dr Eng. 


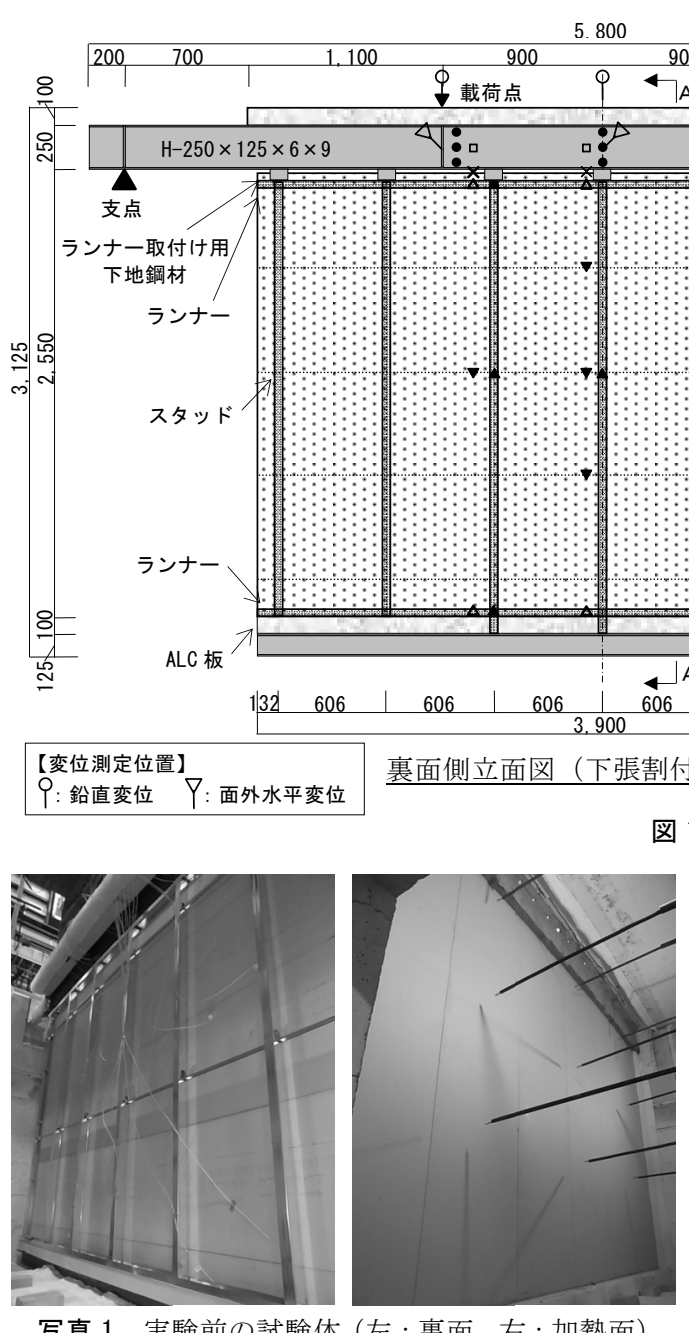

写真 1 実験前の試験体（左 : 裏面，右 : 加熱面 $)$

1 実大試験体（寸法の単位：mm)

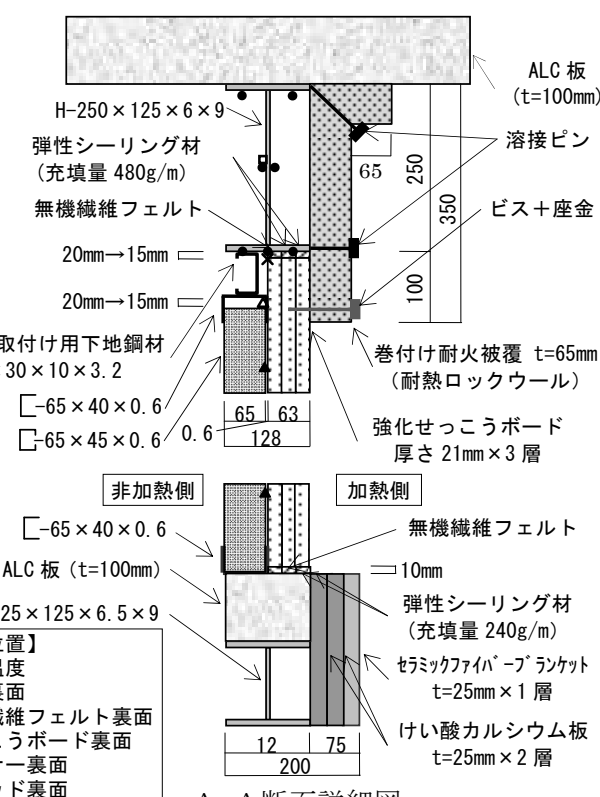

A-A断面詳細図

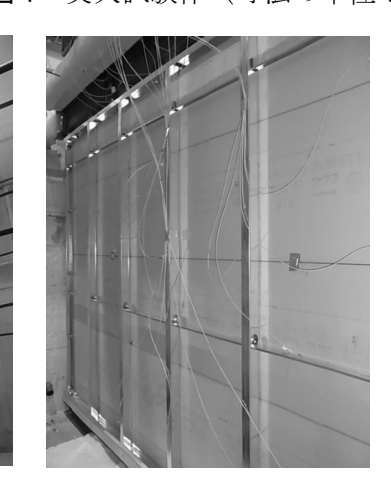

写真 2 実駼後の試験什
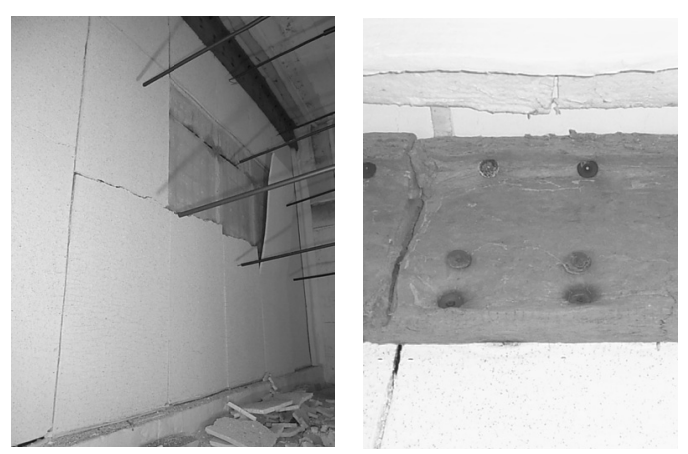

加熱面被覆部見上げ)
間仕切壁の有効加熱面積は W: $3,900 \times H: 2,550 \mathrm{~mm}$ である。加熱温度は IS0834 標準加熱曲線に準じ，2 時間加熱とした。

(3) 測定項目

梁の鋼材温度および合成区画構成材料の裏面温度を図 1 に示寸位 置で測定するとともに, 炉内温度を測定した。鋼材温度は, 鋼材表面 に深さ $2 \mathrm{~mm}$ 程度の孔を開け, そこに $\mathrm{K}$ 型熱電対の先端を埋め込み固 定して測定した。裏面温度は先端に銅製の円板が付いた $K$ 型熱電対 $(\phi 0.65 \mathrm{~mm})$ を試験体に押し付け，その背面を耐火繊維パッド $(30 \mathrm{~mm}$ 角)で覆い測定した ${ }^{4)}$ 。また, 梁の鉛直变位と面外水平変位 (材軸に 対して垂直な方向の水平変位) を梁中央と載荷点で測定した。

\section{3 実験結果}

\section{(1) 経過概要}

実験は, 2 時間加熱終了後, 試験体各部の温度の低下が確認され るまで継続して行った。実験前後の試験体の状況を写真 1,2 に示す。 加熱側では, 加熱開始後約 50 分に, 上張りせっこうボードの目地の 開きが認められたが, 加熱終了まで脱落することはなかった。写真 2 で上張りせっこうボードが脱落しているが，これは冷却期間中に 生じたものである。非加熱側では, 加熱開始後 6 20 分に左下隅か ら若干の発煙があったが, その後, 大きな変化は認められなかった。

\section{(2) 梁の鋼材温度と変形}

炉内温度および梁中央部の鋼材温度の経時変化を図 2 に示す。ま た, 梁の鉛直変位と面外水平変位の経時変化を図 3 に示す。鋼材温
度は加熱側の方が裏面側に比べて $25 \sim 50^{\circ} \mathrm{C}$ 程度高くなった。そして, 上フランジの方が下フランジよりも温度が高く, その最大温度差は 加熱側で約 $100^{\circ} \mathrm{C}$, 裏面側で約 $50^{\circ} \mathrm{C}$ あっった。これらの温度性状に よって, 図 3 に示されるように, 加熱時の梁において上に凸の鉛直 変位と加熱側に凸の面外水平変位を生じたと言える。

実験時における梁中央部の鉛直変位は最大で上方に約 $3.5 \mathrm{~mm}$, 下 方に約 $2 \mathrm{~mm}$ であった。加熱前の梁中央部のスタッド上端とランナー 下面の隙間が約 $15 \mathrm{~mm}$ だったのに対し, ランナーの溝の深さは $40 \mathrm{~mm}$ あることから, 加熱により生じた梁の鉛直変位に伴う間仕切壁への 鉛直荷重の伝達はなかったと言える。また, 梁の面外水平変位は加 熱側に最大で約 $3 \mathrm{~mm}$ であった。梁一間仕切壁の相互作用の影響をも っとも受けやすいと考えられるシール部と上部ランナーを実験後に 目視観察したところ, 隙間や変形などの損傷は認められなかった。

後述する梁の裏面温度の測定結果等から判断すると, 梁の裏面温 度上昇が遮熱性能上の許容温度上昇以下であれば, 梁と間仕切壁の 相互作用による非損傷性への顕著な影響はないものと判断される。

( 3 ）合成区画構成材料の裏面温度

梁・ランナー・スタッド・せっこうボード・壁上端目地の各裏面 温度の経時変化を図 4 に示す。前項の非損傷性の検討で着目したシ 一ル部(無機繊維フェルト)および上部ランナーの裏面温度に急激な 変化等は見られない。このことから, 遮熱性に関しても, 梁と間仕 切壁の相互作用による顕著な影響はなかったものと判断される。 


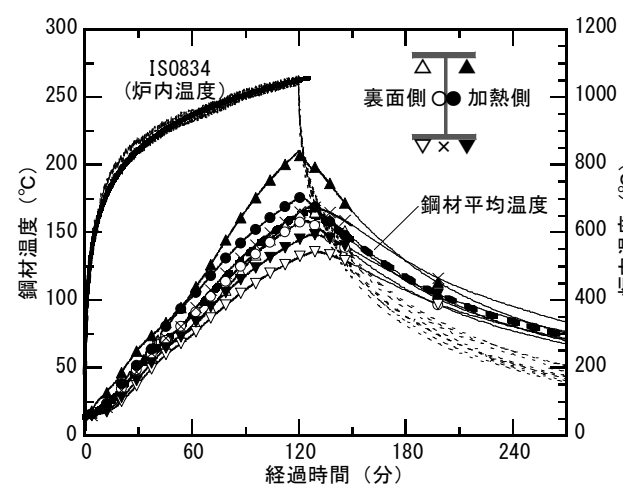

図 2 炉内温度および梁鋼材温度

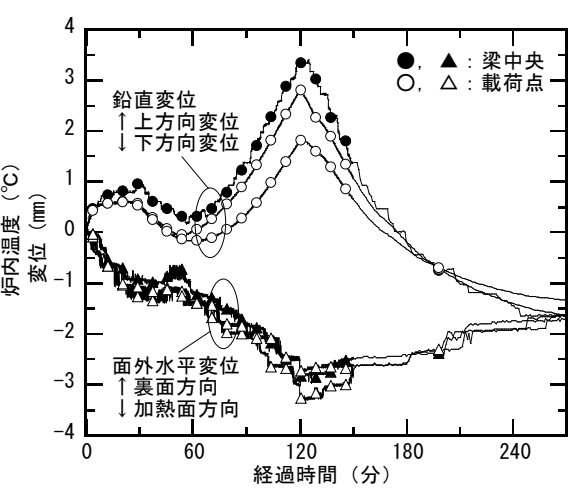

図 3 梁の変位

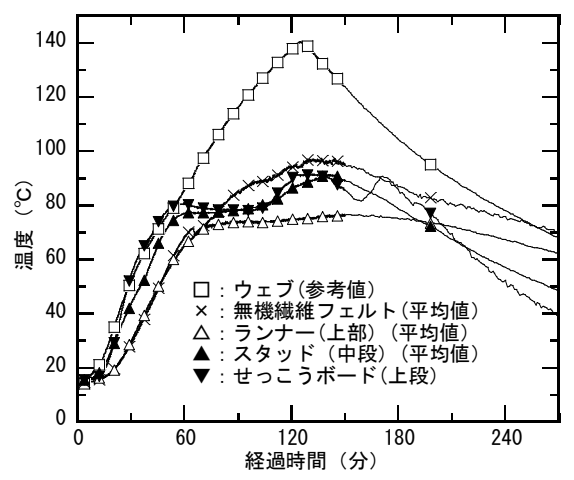

図 4 合成区画構成材料の裏面温度
各温度測定点における最高温度上昇 (測定温度の最高值から初期 温度 $13^{\circ} \mathrm{C}$ 差し引いた值) の範囲と平均值を表 1 に示す。梁ウェブ の裏面温度は梁中央と載荷点付近の 3 点で測定したが, 実験終了ま

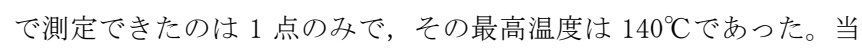
該裏面温度とほぼ同位置の鋼材温度の最高值は $129^{\circ} \mathrm{C} て ゙$, 両者の差 は $11^{\circ} \mathrm{C}$ である。この温度差は耐火繊維パッドの断熱効果の影響によ るものと考えられる。後述の部分模型試験体の実験結果 (表 3)の $\mathrm{H} 250$ シリーズにおいて, 非加熱側ウェブ鋼材温度 $\left(130 \sim 169^{\circ} \mathrm{C}\right)$ とウ エブ(中) 裏面温度 $\left(144 \sim 171^{\circ} \mathrm{C}\right)$ の温度差は $0 \sim 15^{\circ} \mathrm{C}$ であるこれら の結果から, 非加熱側の鋼材温度が $170^{\circ} \mathrm{C}$ 程度までならば, 非加熱 側の鋼材温度の最高温度上昇に 0 ～15K を加算することで, 耐火繊維 パッドの断熱効果を加味した梁裏面温度の最高温度上昇が推定でき るものと考えられる。表 1 の梁裏面温度の最高温度上昇は, 非加熱 側の鋼材温度の最高温度上昇に $11 \mathrm{~K}$ を加算して求めた推定値である。

遮熱性の評価において, 裏面温度上昇の許容值は平均で $140 \mathrm{~K}$, 最 高で $180 \mathrm{~K}$ である ${ }^{5)}$ 。本実験では, 表 1 に示すように梁の裏面温度上 昇が他の区画構成材料よりも高く, 平均で $135 \mathrm{~K}$, 最高で $164 \mathrm{~K}(15 \mathrm{~K}$ を加算した場合でも平均で $139 \mathrm{~K}$, 最高で 168K）と推定され, 本実験 に供した合成区画は 2 時間の遮熱性能を有するものと推定される。

\section{3. 部分模型試験体の加熱実験}

\section{1 試験体}

実大試験体の載荷加熱実験の結果, 梁の鋼材部における裏面温度 は他の部分の裏面温度よりも高くなることが確認された。このこと から, 部分模型試験体による合成区画の仕様の検討では, 梁温度に 着目することとし, 鉄骨の断面寸法, 耐火被覆厚および耐火被覆の断 面形状を実験因子として試験体を製作した。

試験体の種類を表 2 に示す。試験体名は, 梁の断面寸法・被覆厚 さ・被覆断面形状・せっこうボード層数を示す表記とした。試験体 は 6 種類で各 1 体ずつ製作した。代表例として試験体 H250-40I-2 と H 250-40L-3 を図 5 に示す。梁の断面寸法は H- $250 \times 125 \times 6 \times 9$ と H-400×200×8×13(いずれもSS400) とした。耐火被覆には, 実大試 験体と同じ巻付けタイプの耐熱ロックウールを用いた。巻付け耐火 被覆の断面形状は間仕切壁の配置によって 2 種類を設定した。一つ は加熱側の下フランジ小口面と間仕切壁表面が一致する仕様 (以下, I 形被覆という) である。もう一つは下フランジに耐火被覆が回り込 むように間仕切壁の加熱面をセットバックさせ, 加熱側 1 層分のせ っこうボードが下フランジにラップするように配置した仕様(以下, L 形被覆という) である。H250-40I-2 以外の間仕切壁は, 実大試験
表 1 鋼材温度と裏面温度の最高温度上昇の範囲と平均値

\begin{tabular}{|c|c|c|c|c|c|c|}
\hline \multirow{2}{*}{ 温度種類 } & \multirow{2}{*}{\multicolumn{2}{|c|}{ 部位 }} & \multicolumn{2}{|c|}{ 最高温度上昇 $(\mathrm{K})$} & \multicolumn{2}{|c|}{ 到達時間 (分) } \\
\hline & & & 範囲 & 平均 & 範囲 & 平均 \\
\hline \multirow{6}{*}{ 鋼材温度 } & \multirow{3}{*}{ 加熱側 } & 上フランジ & $126-197$ & 152 & $120-124$ & 121 \\
\hline & & ウェブ & $137-163$ & 146 & $122-125$ & 123 \\
\hline & & 下フランジ & $136-156$ & 145 & $127-132$ & 130 \\
\hline & \multirow{3}{*}{$\begin{array}{c}\text { 非加熱 } \\
\text { 側 }\end{array}$} & 上フランジ & $104-153$ & 122 & $126-133$ & 129 \\
\hline & & ウェブ & $116-146$ & 129 & $123-125$ & 126 \\
\hline & & 下フランジ & $108-123$ & 114 & $130-132$ & 130 \\
\hline \multirow{8}{*}{ 裏面温度 } & \multirow{3}{*}{ 鉄骨梁 } & 上フランジ & $115-164$ & 133 & - & - \\
\hline & & ウェブ & $127-157$ & 140 & - & $\overline{-}$ \\
\hline & & 下フランジ & $119-134$ & 125 & - & - \\
\hline & \multicolumn{2}{|c|}{ 無機繊維フェルト } & $74-105$ & 85 & $127-144$ & 134 \\
\hline & \multicolumn{2}{|c|}{ 上部ランナー } & $63-66$ & 64 & $135-153$ & 146 \\
\hline & \multicolumn{2}{|c|}{ 下部ランナー } & $63-74$ & 70 & $119-120$ & 120 \\
\hline & \multicolumn{2}{|c|}{ スタッド } & $62-83$ & 75 & $120-164$ & 141 \\
\hline & \multicolumn{2}{|c|}{ せっこうボード } & $61-88$ & 71 & $57-192$ & 111 \\
\hline
\end{tabular}

表 2 部分模型試験体の種類

\begin{tabular}{|c|c|c|c|c|c|}
\hline \multirow{2}{*}{ 試験体記号 } & \multirow{2}{*}{ 鉄骨梁断面 (mm) } & \multicolumn{2}{|c|}{ 巻付け耐火被覆 } & \multirow{2}{*}{$\begin{array}{c}\text { せっこうボード } \\
\text { 層数 }\end{array}$} & \multirow{2}{*}{$\begin{array}{l}\text { 加熱時間 } \\
\text { (分) }\end{array}$} \\
\hline & & 厚さ $(\mathrm{mm})$ & 断面形状 & & \\
\hline H250-40I-2 & \multirow{3}{*}{$\mathrm{H}-250 \times 125 \times 6 \times 9$} & \multirow{2}{*}{40} & I 形 & 2層 & 90 \\
\hline $\mathrm{H} 250-40 \mathrm{~L}-3$ & & & L 形 & 3層 & 90 \\
\hline H250-65L-3 & & 65 & L 形 & 3層 & 120 \\
\hline H400-40I-3 & \multirow{3}{*}{$\mathrm{H}-400 \times 200 \times 8 \times 13$} & \multirow{2}{*}{40} & I 形 & 3層 & 120 \\
\hline H400-40L-3 & & & L 形 & 3層 & 120 \\
\hline$H 400-65 L-3$ & & 65 & L 形 & 3層 & 180 \\
\hline
\end{tabular}

体と同様に強化せっこうボード 3 層張りとした。H250-40I-2 では 1 時間耐火仕椂になることを予想して, 強化せっこうボード 2 層張り とした。耐火被覆は梁の上下フランジに溶接ピンで固定しただけで, 実大試験体のように間仕切壁に対してビスによる固定はしなかった。

試験体は, 図 5 に示寸ように外周枠 $(H-100 \times 100 \times 6 \times 8)$ の中に梁 と間仕切壁をセットした。外周枠の内法寸法は有効加熱面積 $(\mathrm{H}$ : $1,000 \mathrm{~mm} \times \mathrm{W}: 1,000 \mathrm{~mm})$ に合わせた。梁下端のフランジ面と間仕切壁上 端との隙間は通常 $10 \mathrm{~mm}$ 程度であるが, 隙間を大きくした方が裏面温 度は上昇しやすいと考えて $21 \mathrm{~mm}$ とした。この隙間には, 加熱側のせ っこうボード 1 層目の上端にのみ, 無機繊維フェルトを充填した。

\section{2 実験方法}

(1) 加熱方法

耐火被覆の施工面を加熱側とした。加熱温度は IS0834 標準加熱曲 線に準じ, 各試験体に対して表 2 に示寸時間の加熱を行った。

(2) 測定項目

梁の鋼材温度と区画構成材料の裏面温度を図 5 に示寸位置で測定 し, かつ炉内温度を測定した。鋼材温度と裏面温度の測定方法は実大 試験体と同様にした。ただし, 梁の裏面温度測定用の熱電対は, 実 験中に剥がれ落ちないように, 耐火繊維パッドの上からステンレス 䇴を押し当てて,ステンレス簿を鋼材にスポット溶接して固定した。 


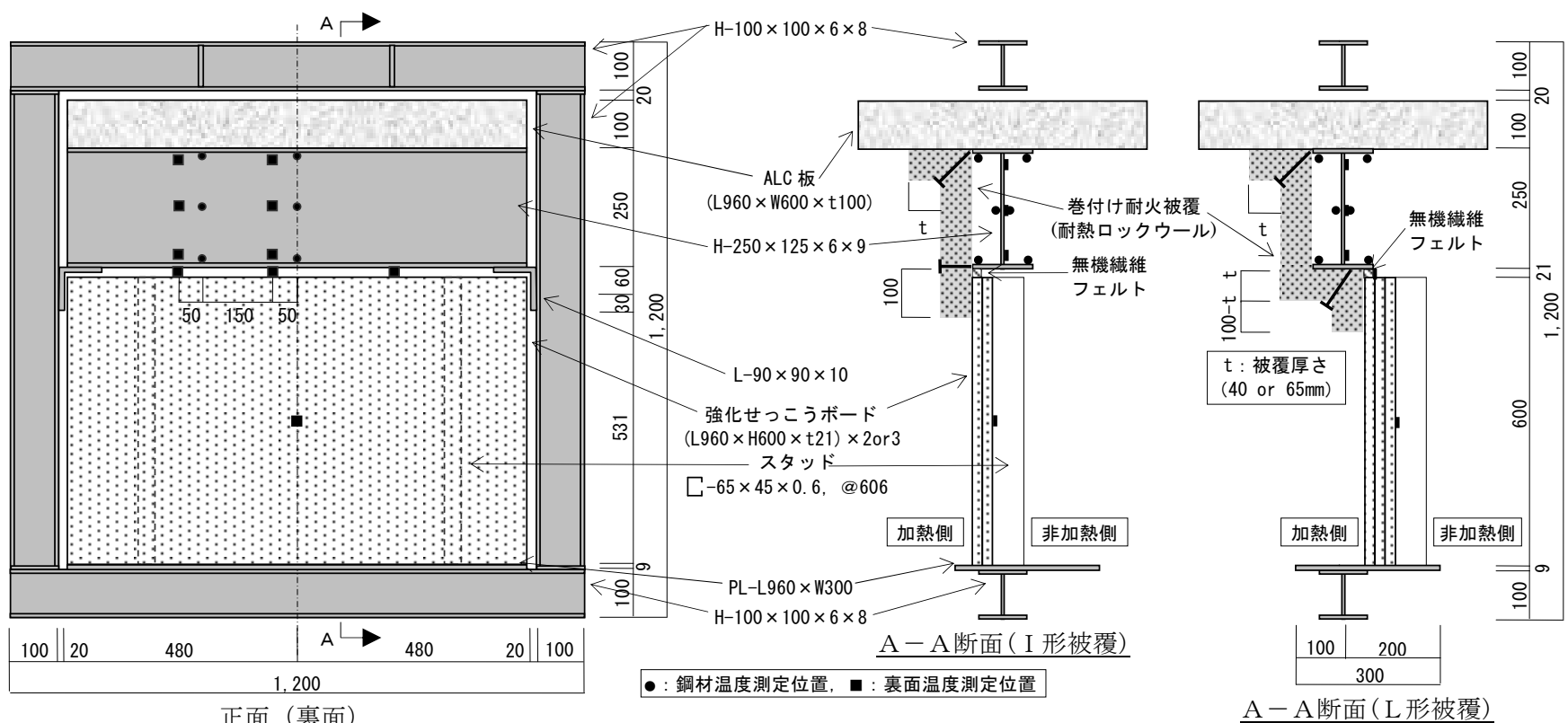

図 5 部分模型試験体（H250-40I-2，H250-40L-3）（寸法の単位：mm）

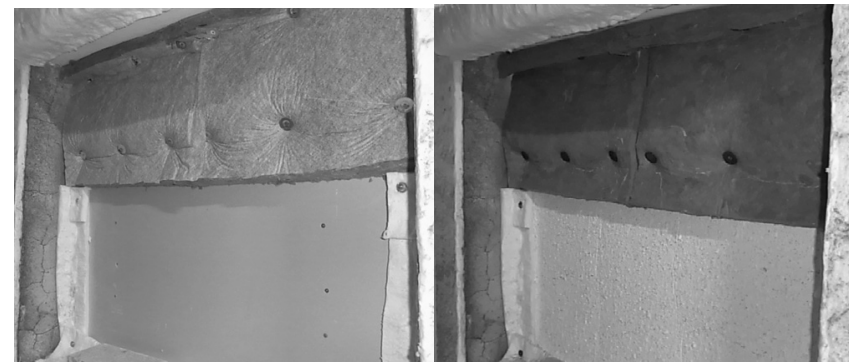

写真 3 試験体 H250-40I-2（左 : 実験前, 右 : 実験後）

\section{3 実験結果}

(1) 経過概要

H250-40I-2 と H250-40L-3 の加熱前後の試験体の状況を写真 3，4 に示寸。耐火被覆は梁の上下フランジに溶接ピンで固定しただけだ が，加熱後の観察において耐火被覆とせっこうボードの間に隙間は 生じていなかった。また，無機繊維フェルト充填部や他の区画構成 材料の取り合い部にも隙間は生じていなかった。加熱初期にせっこ うボードから発生した煙や水蒸気がシール部の裏面側で観察された が,これは弾性シーリング材を充填しなかったためだと考えられる。

(2) 梁の鋼材温度および合成区画構成材料の裏面温度

図 6 に代表例として, 試験体 H250-40I-2, H250-40L-3, H400-40I-3 および H400-40L-3 に関して, 炉内温度と梁中央部の鋼材温度, およ びウェブ・せっこうボード・シール部無機繊維フェルトの裏面温度 の経時変化を示す。L 形被覆では下フランジの加熱面積が増えるた め, I 形被覆よりも下フランジの鋼材温度が高くなった。H400-40I-3 の加熱側鋼材温度は上フランジよりも下フランジの方が若干高くな ったが，その一因として，耐火被覆どうしを突き付けた位置のせっ こうボードに幅約 $5 \mathrm{~mm}$ の縦方向のひび割れが生じた影響が考えられ る。L 形被覆において測定したシール部無機繊維フェルトの裏面温 度は, ウェブの裏面温度よりも低かった。シール部には弾性シーリ ング材を充填しなかったが，実大試験体の実験結果と同様に，合成 区画の遮熱性はシール部ではなく梁の裏面温度で決まると言える。

各試験体の鋼材温度および裏面温度の最高温度上昇の範囲と平均

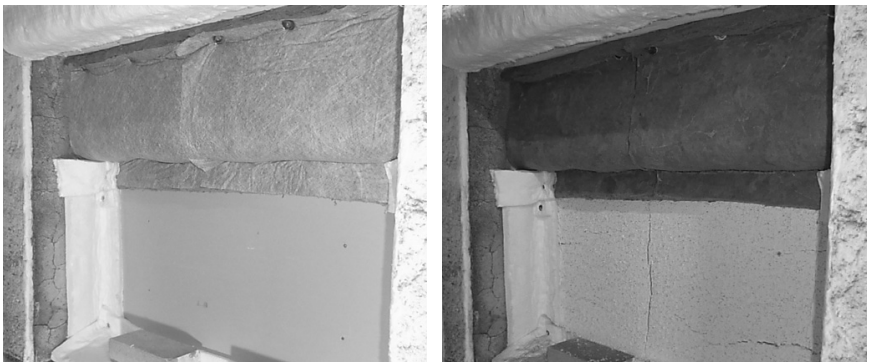

写真 4 試験体 H250-40L-3（左 : 実験前, 右 : 実験後)

值を表 3 に示す。I 形被覆と L 形被覆における梁裏面温度の最高温 度上昇の最高值と平均值は, 非加熱側の鋼材温度や他の区画構成材 料の裏面温度に関する最高温度上昇よりも高くなっている。このこ とから, 本実験においては, ウェブ高さの上・中・下で裏面温度を 測定しておけば，遮熱性の評価ができるものと判断される。

（3）本開発における合成区画の耐火時間の上限

3 時間加熱した H400-40L-3の上張りせっこうボードは脱落しなか ったが, メーカーの自主試験によると, 実大の間仕切壁では 2 時間 を越える加熱で上張りの脱落が確認されている。上張りが脱落する と耐火被覆と間仕切壁の取合い部に隙間が生じるため, 本開発の合 成区画仕様の耐火時間は 2 時間を上限とするのが妥当である。

\section{4. 合成区画を構成する梁の鋼材温度と裏面温度の簡易算定}

実大試験体および部分模型試験体の実験結果から，合成区画の遮 熱性は梁の裏面温度で評価できることが確認された。そのため, 合 成区画の梁の裏面温度を予測・評価できれば, 要求性能を満たす合 成区画の設計が可能になると言える。本章では, 耐火性能検証法 ${ }^{2)}$ における鋼材温度算定式の考え方を適用して, 合成区画を構成する 梁の鋼材温度の算定式を導くとともに, 鋼材温度と梁裏面温度の関 係を把握することにより，梁の裏面温度の予測方法を提案する。

\section{1 鋼材温度の算定式}

鋼材温度の算定式は，式(1) と式(2)で定義されている ${ }^{2)}$ 。式 (2) の断面積 $A_{i} \cdot A_{s}$ および外周長 $H_{i} \cdot H_{s}$ は図 7 に示すように採った。 


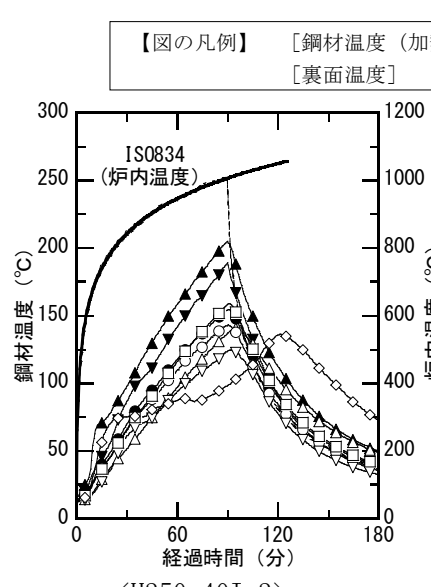

$\langle$ H250-40I-2〉

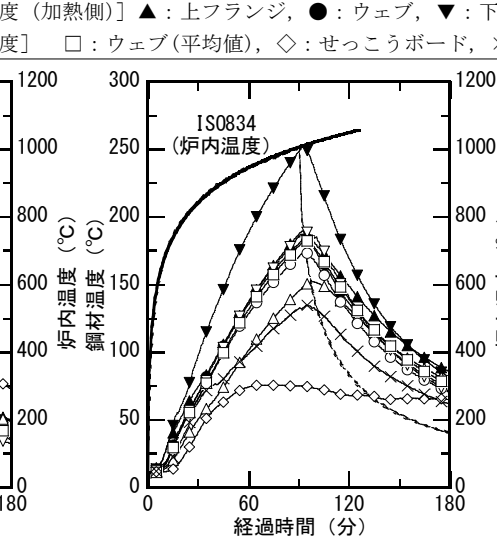

$\langle\mathrm{H} 250-40 \mathrm{~L}-3\rangle$

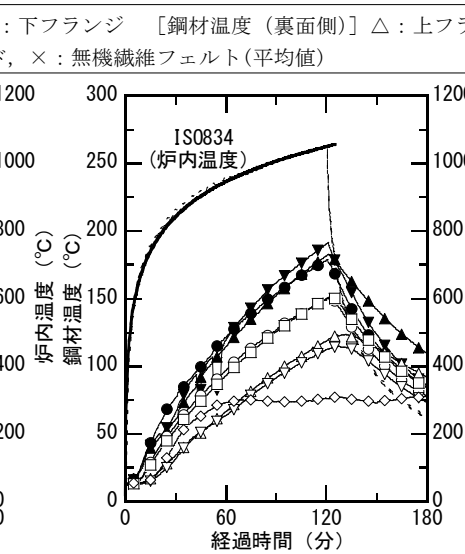

$\langle$ H400-40I-3〉

図 6 部分模型試験体の温度測定結果

表 3 鋼材温度と裏面温度の最高温度上昇の測定值と平均值

\begin{tabular}{|c|c|c|c|c|c|c|c|c|c|c|c|c|c|c|}
\hline \multirow{3}{*}{$\begin{array}{l}\text { 温度 } \\
\text { 種類 }\end{array}$} & & \multirow{3}{*}{ 部位 } & \multicolumn{12}{|c|}{ 最高温度上昇 $(K)$} \\
\hline & & & \multicolumn{2}{|c|}{ H250-40I-2 (90分加熱) } & \multicolumn{2}{|c|}{ H250-40L-3(90分加熱) } & \multicolumn{2}{|c|}{ H250-65L-3(120分加熱) } & \multicolumn{2}{|c|}{ H400-40I-3(120分加熱) } & \multicolumn{2}{|c|}{ H400-40L-3(120分加熱) } & \multicolumn{2}{|c|}{ H400-65L-3(180分加熱) } \\
\hline & & & 測定値 & 平均 & 測定値 & 平均 & 測定値 & 平均 & 測定値 & 平均 & 測定値 & 平均 & 測定値 & 平均 \\
\hline \multirow{6}{*}{ 鋼材 } & \multirow{3}{*}{$\begin{array}{c}\text { 加熱 } \\
\text { 側 }\end{array}$} & 上フランジ & 187,225 & \multirow{3}{*}{176} & 169,179 & \multirow{3}{*}{195} & 144,151 & \multirow{3}{*}{162} & 170,172 & \multirow{3}{*}{170} & 181,191 & \multirow{3}{*}{219} & 187,190 & \multirow{3}{*}{197} \\
\hline & & ウェブ & 141,151 & & 172,173 & & 146,146 & & 155,166 & & 187,196 & & 162,163 & \\
\hline & & 下フランジ & 175,177 & & 235,242 & & 190,198 & & 179,181 & & 273,288 & & 241,242 & \\
\hline & \multirow{3}{*}{$\begin{array}{l}\text { 非加 } \\
\text { 熱側 }\end{array}$} & 上フランジ & 128,147 & \multirow{3}{*}{129} & 135,141 & \multirow{3}{*}{161} & 118,122 & \multirow{3}{*}{139} & 111,119 & \multirow{3}{*}{114} & 131,131 & \multirow{3}{*}{161} & 126,135 & \multirow{3}{*}{143} \\
\hline & & ウェブ & 130,148 & & 163,169 & & 140,145 & & 122,138 & & 153,167 & & 133,140 & \\
\hline & & 下フランジ & 112,116 & & 178,182 & & 155,155 & & 99,102 & & 193,197 & & 162,167 & \\
\hline \multirow{5}{*}{$\begin{array}{l}\text { 裏面 } \\
\text { 温度 }\end{array}$} & \multirow{3}{*}{$\begin{array}{c}\text { 鉄骨 } \\
\text { 梁 }\end{array}$} & ウェブ(上) & 148,166 & \multirow{3}{*}{146} & 153,157 & \multirow{3}{*}{172} & 132,133 & \multirow{3}{*}{146} & 141,144 & \multirow{3}{*}{139} & 161,161 & \multirow{3}{*}{181} & 149,157 & \multirow{3}{*}{160} \\
\hline & & ウェブ(中) & 145,147 & & 170,171 & & 144,145 & & 146,148 & & 176,180 & & 151,156 & \\
\hline & & ウェブ(下) & 131,139 & & 189,193 & & 158,163 & & 125,131 & & 201,209 & & 173,175 & \\
\hline & \multicolumn{2}{|c|}{ 無機繊維フェルト } & - & - & $116,121,133$ & 123 & $88,91,118$ & 99 & - & - & $138,152,167$ & 152 & $113,124,137$ & 124 \\
\hline & \multicolumn{2}{|c|}{ せっこうボード } & 123 & 123 & 64 & 64 & 67 & 67 & 64 & 64 & 67 & 67 & 118 & 118 \\
\hline
\end{tabular}

$\frac{T_{s}(t)-T_{0}}{T_{f}-T_{0}}=1-\exp \left\{-h\left(t-t_{z}\right)\right\}$

ここに,

$h$ : 部材温度上昇係数 $\left[\mathrm{min}^{-1}\right], T_{s}(t)$ : 鋼材温度 $\left[{ }^{\circ} \mathrm{C}\right], T_{f}$ : 火災温 度 $\left[{ }^{\circ} \mathrm{C}\right], T_{0}$ : 初期温度 $\left[{ }^{\circ} \mathrm{C}\right], t$ : 時間 $[\mathrm{min}], t_{z}$ : 初期温度上昇 の遅延 $\left(t_{0}\right)$ と被覆材内部の含水の蒸発による遅延時間（ $t_{w}$, 本検討では $t_{w}=0$ とする）の和 $[\mathrm{min}]$

$$
h=\frac{\phi K_{0}\left(H_{s} / A_{s}\right)}{\left\{1+\frac{\phi R}{\left(H_{i} / A_{i}\right)}\right\}\left\{1+\frac{\phi}{2} \frac{\left(H_{s} / A_{s}\right)}{\left(H_{i} / A_{i}\right)} C\right\}}
$$

$$
\text { ここに, }
$$

$A_{i}$ : 被覆材料の断面積 $\left[\mathrm{m}^{2}\right], A_{s}$ : 鋼材の断面積 $\left[\mathrm{m}^{2}\right], C\left(\equiv \rho_{i} c_{i} /\right.$ $\left.\rho_{s} c_{s}\right)$ : 被覆材料と鋼材の熱容量比 $\left(\rho_{i}=100 \mathrm{~kg} / \mathrm{m}^{3}\right.$ (厚 $40 \mathrm{~mm}$ ), $\rho_{i}=110 \mathrm{~kg} / \mathrm{m}^{3}$ (厚 $65 \mathrm{~mm}$ ), $\rho_{s}=7860 \mathrm{~kg} / \mathrm{m}^{3}, c_{i}=857 \mathrm{~J} / \mathrm{kg} . \mathrm{K}$ ), $c_{s}=442$ $\mathrm{J} / \mathrm{kg} . \mathrm{K}), H_{i}$ : 被覆材料の外周長 $[\mathrm{m}], H_{s}$ : 鋼材の外周長 $[\mathrm{m}], h_{t}$ : 部材表面と火災空間との間の総合熱伝達率 $\left[\mathrm{W} / \mathrm{m}^{2} . \mathrm{K}\right], K_{0}\left(\equiv h_{t} /\right.$ $\left.\rho_{s} c_{s}=0.00067\right):$ 基本温度上昇係数 $[\mathrm{m} / \mathrm{min}], k_{i}$ : 被覆材料の熱 伝導率 $[\mathrm{W} / \mathrm{m} . \mathrm{K}], R\left(\equiv h_{t} / k_{i}\right)$ : 熱抵抗係数, $\rho$ : 密度 $\left[\mathrm{kg} / \mathrm{m}^{3}\right]$, $\phi\left(\equiv H_{i} / H_{s}\right):$ 加熱を受ける部分の被覆材料と鋼材の周長比

\section{2 鋼材温度の算定に必要な諸定数の導出および実験結果と計算 結果の比較}

(1) 部材温度上昇係数 $(h)$

$h$ は, 式(1)を変形した式(3)によって求める。具体には, 式(3)の
左辺を $\mathrm{Y}$ 軸, $t$ を $\mathrm{x}$ 軸として, 耐火実験で測定した鋼材温度と時間

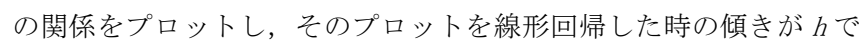
ある。本検討では, 式 (3) 中の鋼材温度として, 加熱側および裏面側 で測定した鋼材温度の平均值 (以下, 鋼材平均温度という)を用いた。 $h$ の導出結果を表 4 に示す。

$$
\log _{e}\left(1-\frac{T_{s}(t)-T_{0}}{T_{f}-T_{0}}\right)=h \cdot\left(t-t_{z}\right)
$$

\section{(2) 熱抵抗比 $(R)$}

$R$ は, 式 (2) を変形した式 (4)において, R以外の変数に既知の值を 代入して求める。具体には, 式 (4)の左辺を $\mathrm{Y}$ 軸, 右辺の $R$ の係数を $\mathrm{X}$ 軸として, 計算值をプロットし, そのプロットを線形回帰した時 の傾きが Rである。ただし, 本検討では, 計算值の線形回帰ではな く, すべての計算值を包含する一次関数によってRを同定した。

$$
\frac{K_{0} \phi\left(H_{s} / A_{s}\right)}{1+\phi C\left(H_{s} / A_{s}\right) / 2\left(H_{i} / A_{i}\right)} \frac{1}{h}=\frac{\phi}{\left(H_{i} / A_{i}\right)} R+1
$$

熱抵抗比 $R$ は， $h_{t}$ を $k_{i}$ で除した特性值として定義されている。本 開発で対象としている梁の裏面は常温の空気と直接触れているため, 対流や放射によって熱損失が生じる。この熱損失は鋼材の温度上昇 の抑制に効果がある。hの導出では実測した鋼材温度を使っている ことから,ここで導出されるRには熱損失効果が考慮されている。 実験結果に基づくRの同定を図 8 に，Rの導出結果を表 4 に示す。 


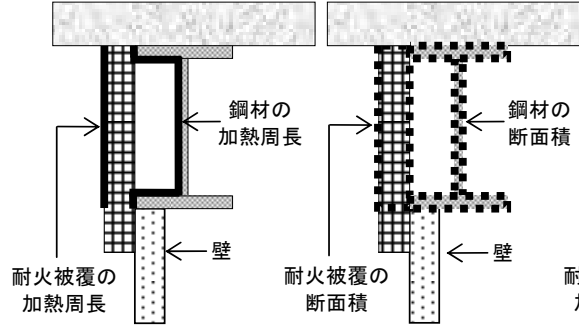

$<\mathrm{I}$ 形被覆断面 $>$

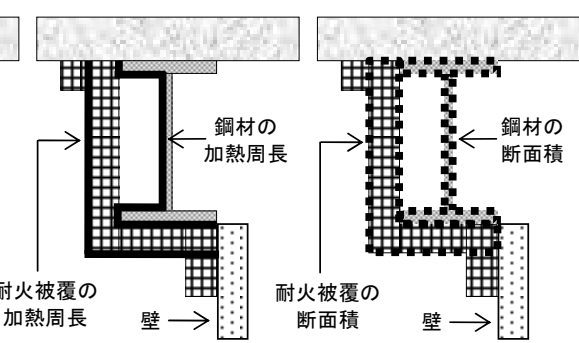

$<\mathrm{L}$ 形被覆断面 $>$
表 4 鋼材温度・裏面温度算定用の諸定数

\begin{tabular}{|c|c|c|c|c|c|}
\hline \multirow[b]{2}{*}{ 試験体記号 } & \multirow{2}{*}{$\begin{array}{c}t_{z}\left(=t_{0}\right) \\
\quad(\text { 分) }\end{array}$} & \multirow{2}{*}{$\begin{array}{c}h \\
\left(\min ^{-1}\right)\end{array}$} & \multirow[b]{2}{*}{$R$} & \multicolumn{2}{|c|}{$\bar{\beta}$} \\
\hline & & & & $\begin{array}{l}\text { 平均 } \\
\text { 温度 }\end{array}$ & $\begin{array}{l}\text { 最高 } \\
\text { 温度 }\end{array}$ \\
\hline H250-40I-2 & 5 & 0.00179 & \multirow{6}{*}{865} & \multirow{6}{*}{0.975} & \multirow{6}{*}{1.094} \\
\hline $\mathrm{H} 250-40 \mathrm{~L}-3$ & 8 & 0.00227 & & & \\
\hline $\mathrm{H} 250-65 \mathrm{~L}-3$ & 16 & 0.00147 & & & \\
\hline $\mathrm{H} 400-40 \mathrm{I}-3$ & 8 & 0.00120 & & & \\
\hline $\mathrm{H} 400-40 \mathrm{~L}-3$ & 8 & 0.00171 & & & \\
\hline H400-65L-3 & 15 & 0.00099 & & & \\
\hline
\end{tabular}

図 7 断面積と加熱周長の採り方

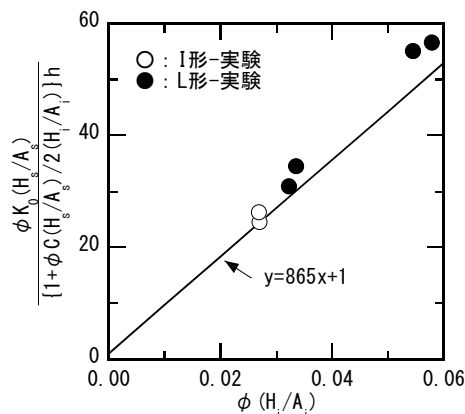

図 8 熱抵抗比 $(R)$ の同定

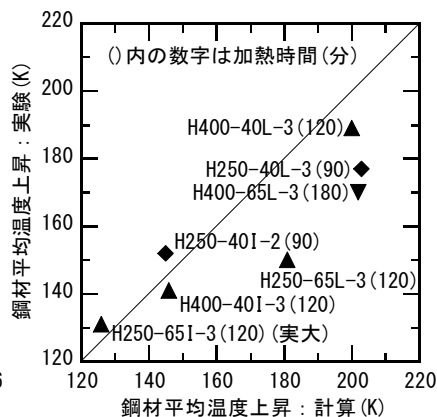

図 9 鋼材平均温度上昇の 計算值と実験值の比較
(3) 実験結果と計算結果の比較

実験結果に基づく鋼材平均温度 (表 3 の加熱側と裏面側の鋼材温 度を合算して求めた平均值) の最高温度上昇と表 4 に示した諸定数 等を式(1), (2)に代入して算定した鋼材の最高温度上昇の比較を図 9 に示す。H250-40I-2 と H250-65I-3 (実大試験体)の計算結果は実験 結果よりも $5 \mathrm{~K}$ 程度低いが, I 形被覆の計算結果は実験結果と概ね一 致している。L 形被覆の計算結果は実験結果よりも最高で $30 \mathrm{~K}$ 程度 高くなったが，これはすべての計算值を包含するようにRを同定し たためであり，L形被覆の計算結果は安全側の予測になっている。

\section{3 梁の鋼材温度からの裏面温度の予測}

実験結果から求めた, 梁ウェブの裏面温度の最高温度上昇の平均 值・最高值と鋼材平均温度の最高温度上昇の関係を図 10 に示す。裏 面温度と鋼材平均温度は比較的高い相関を示している。ただし，鋼 材平均温度上昇が最小の実験結果は実大試験体のものであるが, 裏 面温度上昇の平均值と最高值の差が，概社同様の温度の部分模型試 験体に比べて大きくなっている。この一因として, 実大試験体の裏 面温度 (表 1) が推定值であることが考えられるが，スケール効果の 可能性もあり, 今後検討を要する課題であると言える。図 10 の回帰 直線の傾きは鋼材平均温度を裏面温度に変換する係数 $(\beta$ と称す) で あり,式(1)，(2)で算定される鋼材温度上昇に $\beta$ を乗じることで裏面 温度上昇を予測する。裏面温度上昇の実験結果と計算結果の比較を 図 11 に示す。計算結果は実験結果に対して $-25 \mathrm{~K} \sim+50 \mathrm{~K}$ の範囲に ある。今後さらにデータを蓄積する必要はあるが, ここで検討した 簡易計算によって，裏面温度を概放予測できると考えられる。

\section{5. まとめ}

片側のみを耐火被覆した鉄骨梁と乾式耐火間仕切壁を一体化した 合成区画の実現に向け, 実大試験体の載荷加熱実験によって梁と間 仕切壁の相互作用を把握するとともに，部分模型試験体の加熱実験 によって合成区画の仕様を検討した。本実験検討の範囲では, 梁と

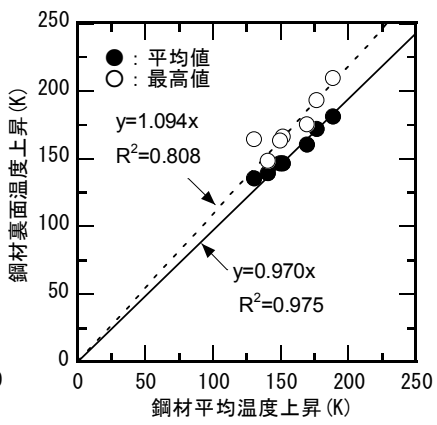

図 10 鋼材平均温度上昇と 鋼材裏面温度上昇の関係

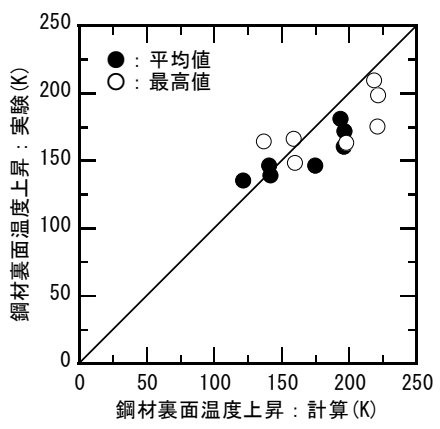

図 11 鋼材裏面温度上昇の 計算值と実験值の比較
間仕切壁の相互作用が耐火性能に及ぼす影響は認められず，遮熱性 能は梁ウェブの裏面温度で概ね評価できることがわかった。また， 合成区画の仕様として, 梁下フランジに対する間仕切壁の設置位置, 梁断面寸法および被覆厚を実験因子として温度性状を検討し，2 時 間耐火性能を有する間仕切壁と組み合わせることによって, H-250 $\times 125 \times 6 \times 9$ では被覆厚 $65 \mathrm{~mm}, \mathrm{H}-400 \times 200 \times 8 \times 13$ では被覆厚 $40 \mathrm{~mm}$ で 2 時間耐火の性能が得られることが把握された。さらに, 耐火時 間・梁断面寸法・耐火被覆厚等の種々の組み合わせ条件に対応する ため, 実験結果に基づき, 耐火性能検証法 ${ }^{2)}$ の考え方に準じて合成 区画を構成する梁の鋼材温度算定式を導出した。そして, 鋼材温度 と裹面温度の関係を把握して, 裏面温度の予測方法を提案した。 本開発成果は，今後，実際の建築物に適用する予定である。

なお，実際の建築物では間仕切壁の両端に柱がある場合も想定さ れ，梁・柱・間仕切壁の相互作用について実験的に検討した例 ${ }^{6)}$ も 報告されており, 今後さらに検討を要する課題であると考える。

\section{参考文献}

1) 森田武: 火㷋時における非耐力耐火間仕切壁の変形性能に関する実験的検 討, 日本建築学会大会学術講演梗概集 A-2, pp. 33 34, 2001

2) 国土交通省住宅局建築指導課他編 : 2001 年版耐火性能検証法の解説及び計 算例とその解説， 2001

3) 湯谷孝夫 他 : 建築構造物の長期設計荷重時応力 (その 2 梁部材), 日本 建築学会大会学術講演梗概集 A-2, pp. 167〜 168, 1997

4) 阪口明弘: 加熱炉特性の試験所間比較試験報告, GBRC Vol. 34 No. 1, pp. 32 $\sim 37$, 日本建築総合試験所, 2009

5）（例えば）一般財団法人日本建築総合試験所：防而火性能試験・評価業務 方法書, 2005

6) Suzuki, J. : Effect of Deformation of Structural Frame on Fire Resistance of Compartmentation, Workshop for Fire-Structure Interaction and Urban and Wildland-Urban Interface (WUI) fires, 2012

[2013 年 6 月 17 日原稿受理 2013 年 8 月 12 日採用決定］ 